\title{
PALABRAS DE HOMENAJE EN HONOR DE DOÑA KERYMA NAVIA PEFAUR, EX-MINISTRO DE LA I. CORTE DE APELACIONES DE LA SERENA
}

\author{
José Pavisic Dragnic
}

Las cenizas caían lentamente en las aguas del Río Arno, mientras en Florencia también caía la tarde; otro tanto había ocurrido en Ovalle, la ciudad que la vio nacer, en un arroyuelo y junto a un pequeño puente que fue testigo de sus juegos de niña. Se había cumplido su postrer deseo. Así, mientras su materialidad se confundía con el líquido elemento, su espíritu comenzaba a aletear entre los que la conocieron.

Dotada de una personalidad muy definida, había ingresado muy joven al mundo del Derecho y de la Justicia. Su dedicación al estudio de los fallos era esmerado, y entregaba a ellos el tiempo que estimaba necesario. El interés por agotar todas las vertientes del problema, quedaba expresado en la redacción de las sentencias. Sobre todo en los votos disidentes, sobre los cuales se podía discrepar, lo que no impedía apreciar el trabajo de análisis que se observaba en ellos. Cualquier jurisprudencia o disposición inmersa en el profundo mar de las leyes era detenidamente examinado, si a su parecer llevaba a una conclusión jurídica que estimaba fundante y acorde con su tesis.

Keryma Navia Pefaur se consagró al Derecho y más propiamente a la Justicia toda su vida, desvelo sólo comparable al que empleó en sus hijos.

Entregada por entero a la actividad judicial, y después de un largo camino andado en las ásperas vías de la administración de justicia, se planteó también ella la duda: si había hecho lo justo; eterna interrogante que se plantea el hombre al dar término a una larga faena: si en realidad se empleó el tiempo justo en lo que realmente valía.

Parece ser como si la recordada colega hubiese querido lograr el imposible de tener la totalidad del tiempo para cada uno de sus objetivos: ser juez y madre a la vez.

Al promediar la década pasada, los integrantes de la Corte vivieron momentos saturados de pena: dos compañeros de trabajo habían fallecido trágicamente. Los hechos ocurridos impactaron fuertemente en el ánimo de los integrantes del Tribunal, produciendo cambios que obligaban a replantearse asuntos, como el sentido de la vida y otros valores. La Ministro no fue ajena a este impacto; en ella se agregó un ingrediente más de humanidad a sus determinaciones, lo que la llevaría a ponderar otros, como la protección de la vida del que está por nacer.

Quienes estaban cerca de su intimidad pudieron verla gozar con la música. Vibraba con los tangos, y así, mientras sus ágiles dedos urdían una malla de finos hilos. que servirían como tantas otras para adorno en su hogar, se deleitaba con las composiciones de Discépolo o Le Pera, o con la voz de Gardel en su inmortal "Cumparsita". En la tarde, cuando su inspiración la motivaba, tomaba el bandoneón y arrancaba de él torrentes de música latina. 
Dios, a quien siempre concibió como esencia de la bondad, le había dado grandes talentos, que ella, a pesar que a veces lo dudó, los había administrado sabiamente. Impulsiva, apasionada, sensible y laboriosa, dejó un estilo difícil de olvidar. 